\title{
Bewegingswetenschappen in beweging
}

Citation for published version (APA):

Huson, A., \& Kuipers, H. (1992). Bewegingswetenschappen in beweging. Maastricht University. https://doi.org/10.26481/spe.19921029hk

Document status and date:

Published: 29/10/1992

DOI:

10.26481/spe.19921029hk

Document Version:

Publisher's PDF, also known as Version of record

\section{Please check the document version of this publication:}

- A submitted manuscript is the version of the article upon submission and before peer-review. There can be important differences between the submitted version and the official published version of record.

People interested in the research are advised to contact the author for the final version of the publication, or visit the DOI to the publisher's website.

- The final author version and the galley proof are versions of the publication after peer review.

- The final published version features the final layout of the paper including the volume, issue and page numbers.

Link to publication

\footnotetext{
General rights rights.

- You may freely distribute the URL identifying the publication in the public portal. please follow below link for the End User Agreement:

www.umlib.nl/taverne-license

Take down policy

If you believe that this document breaches copyright please contact us at:

repository@maastrichtuniversity.nl

providing details and we will investigate your claim.
}

Copyright and moral rights for the publications made accessible in the public portal are retained by the authors and/or other copyright owners and it is a condition of accessing publications that users recognise and abide by the legal requirements associated with these

- Users may download and print one copy of any publication from the public portal for the purpose of private study or research.

- You may not further distribute the material or use it for any profit-making activity or commercial gain

If the publication is distributed under the terms of Article $25 \mathrm{fa}$ of the Dutch Copyright Act, indicated by the "Taverne" license above, 


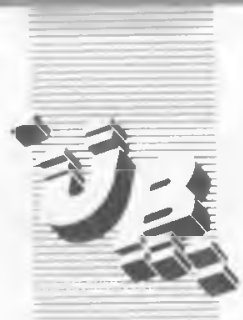

De ultleentermijn verstrijkt op

\section{JAN. 1993 \\ 15 MARI 1993}

Rıkksuniversiteıt Lımburg

Postbus 616

6200 MD Maastricht

3 ÄPR. 1993

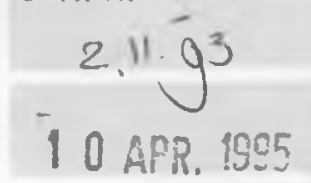

- 3 A.PR. 1950

Gelieve deze publicatıe tijdig te retourneren of (telefonisch) verlenging van de uitleentermijn aan te vragen

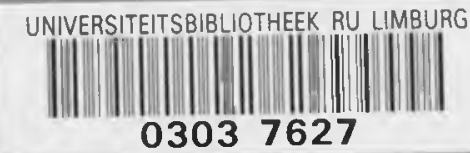


rede uitgesproken bij de aanvaarding van het ambt van hoogleraar in de Bewegingswetenschappen

Faculteit der Gezondheidswetenschappen

van de Rijksuniversiteit Limburg

op donderdag 29 oktober 1992

door

Dr. A. Huson 


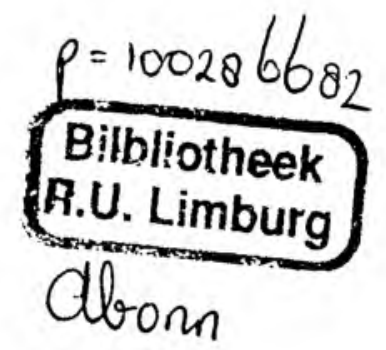


Meneer de rector, leden van de universitaire gemeenschap, zeer geachte toehoorders,

Wie op de leerstoel Bewegingswetenschappen gaat zitten om vanaf die plaats zijn academische taak te vervullen moet een overmoedig mens zijn. Want wat zal de inhoud van zijn onderwijs dan zijn en waarop zal zijn onderzoek zich gaan richten? Had mijn voorganger, die als vakgroepvoorzitter de vijfpotige leerstoel voor een deel bezette, het bij zijn afscheidscollege al moeilijk met de afgrenzing van zijn omvangrijke leergebied "Humane Biologie", hij kon zich nog verheugen in de toevoeging humaan. In het geval van Bewegingswetenschappen moet dit maar stilzwijgend worden verondersteld, want anders zou het vakgebied uitdijen tot een volledige "Animale Biologie", met zelfs grensoverschrijdingen naar de "loslopende" eencelligen uit het plantenrijk.

Bewegen, en dan bedoel ik snel bewegen, sneller dan wat wij aan bewegingen bij planten kunnen waarnemen, werd in de evolutie mogelijk door het ontstaan van samentrekbare eiwitten, lange molecuulketens behorende tot het eiwit-assortiment, dat bij veelcelligen de zogenaamde actines en myosines omvat ${ }^{(1)}$. In de evolutie-biologie is deze "uitvinding" een ongehoorde prestatie geweest en één met geweldige perspectieven. Daarbij doel ik niet op de gebeurtenis van hedenmiddag. Nee, dit wapenfeit markeert globaalweg de grens tussen plantaardig en dierlijk leven en het zich vrij kunnen bewegen ten opzichte van zijn omgeving is het wezenskenmerk van bijna al het 
dierlijk, en laat ik ter genoegdoening van ons ego er maar expliciet bij zeggen, menselijk leven, want over dat laatste zal het in het vervolg vooral gaan.

Rechtvaardigt het belang van dit biologisch aspect het bestaan van deze leerstoel, de veelomvattendheid ervan noodzaakt tegelijkertijd tot afgrenzing, waarover zo aanstonds meer. Want het fenomeen bewegen is niet alleen voor de wetenschap een belangrijk onderwerp, het is dit ook in maatschappelijk opzicht. Verstarring, verlies van motiliteit en mobiliteit is een bedreiging voor zowel het individuele leven als voor de samenleving in zijn geheel, hetzij direct, dan wel op langere termijn.

Afgrenzing zal dus nodig zijn, maar ik wil dit toch nog even uitstellen en nog een ogenblik stil staan bij de veelzijdigheid van het thema bewegen. Die veelzijdigheid brengt er ons toe om bewegingswetenschappen multi- of interdisciplinair te noemen. Of de spreker voorkeur heeft voor het begrip multi-, dan wel interdisciplinair lijkt daarbij af te hangen van zijn imperiale, respectievelijk innoverende ambities. Om elke twijfel over mijn motieven weg te nemen zeg ik bij deze gelegenheid meteen maar hoe ik deze termen zal gebruiken en dan heb ik ze eigenlijk beide nodig. Ik zou het betreffende onderzoeksveld zelf interdisciplinair willen noemen, wanneer dat problemen in studie neemt, die voor hun oplossing om een benadering vanuit verschillende disciplines vragen, zodat de aanpak van deze problemen dan veeleer een multidisciplinaire genoemd moet worden. Omdat bewegingswetenschappen worden gekenmerkt door de integratie van benaderingen en de kennis uit verschillende disciplines zou het zich daarmee onderscheiden van de zogenaamde monodisciplinaire wetenschapsgebieden. 
Mono, multi of inter?

Zogenaamd, want het onderscheid tussen mono-, multi- en interdisciplinaire wetenschapsgebieden is minder principieel dan de discussies daarover wel eens willen doen geloven. Dat maakt een voorbeeld heel dicht bij huis al duidelijk. Fvsiologie. in goed Nederlands de leer der levensverrichtingen, die volgens deze definitie ook bewegingswetenschappen zou omvatten (ja, $U$ heeft het goed gehoord), en anatomie. letterlijk de ontleedkunde, worden beide op de klassieke landkaart van de medische wetenschappen als twee funderende basisvakken en vanuit die traditie haast vanzelfsprekend als monodisciplinaire wetenschapsgebieden beschouwd.

Welnu, wanneer zoals eerder werd vastgesteld, bewegingswetenschappen multidisciplinair zou zijn moet dat a forteriori ook voor fysiologie gelden. Maar ook in ander opzicht is de terminologie inconsistent, want de naam anatomie is afgeleid van één van de in dit gebied van oudsher toegepaste technieken, benadrukt dus de methodologische zijde van het onderzoek, terwijl de term fysiologie veeleer verwijst naar de aard van het veld van onderzoek en dus de vraagstelling benadrukt.

Daarmee zijn deze naamgevingen in feite vooral historisch gekwalificeerd, want de levensverrichtingen zijn niet op zinvolle wijze te bestuderen zonder daarbij de die levensverrichtingen dienende structuren te betrekken en het bestuderen van de structuren krijgt pas goed reliëf wanneer dat tegen de achtergrond van hun functie gebeurt. Dat betekent niet dat deze als voorbeeld gekozen "monodisciplines" (wij hadden het nog steeds over het voorbeeld anatomie en fysiologie) ineens identiek aan elkaar zijn geworden, want tussen deze twee is er 
inderdaad een wetenschaps-theoretisch verschil aanwijsbaar ${ }^{(2)}$.

Binnen elk van deze zogenaamde monodisciplines zijn steeds meer aangrenzende kennisdomeinen met hun eigen gereedschap opgenomen, zodat elk van deze zogenaamde mono-disciplines een ontwikkeling naar toenemende complexiteit heeft ondergaan. Zij zijn zelf in de loop van hun ontwikkeling al meer en meer multidisciplinair van aard geworden. En de onderzoekers, die werkzaam zijn in zo'n als monodiscipline beschouwd vakgebied hebben vaak een zekere "verkleuring" ondergaan. Daarnaast worden er ook nieuwe wetenschapsgebieden ontgonnen tussen de al bestaande in. Biomedische technologie is zo'n interdisciplinair veld. Ik denk dat de ontwikkeling van bewegingswetenschappen ook zo'n voorbeeld is.

\section{Bewegingswetenschappen: drie invalshoeken}

Bewegingswetenschappen vraagt dus om een multidisciplinaire benadering. De vakgroep Bewegingswetenschappen kan vanuit zo'n ruime invalshoek het basale en toegepaste bewegingsonderzoek aanpakken dankzij de multidisciplinaire samenstelling van de vakgroep. Dat is overigens, nationaal zowel als internationaal, een opvallend kenmerk van onderzoeksgroepen die zich bezig houden met bewegingswetenschappen. De in onze vakgroep aanwezige deskundigheid gerangschikt in alfabetische volgorde naar hun disciplines van herkomst, omvat:

(functionele) anatomie, biochemie, biologie, biomechanica, civiele techniek, experimentele psychologie met een accent op functieleer, fysiologie en werktuigbouwkunde. 
Ook de onderzoekers die samen het lijstje van de zojuist opgesomde deskundigheden inbrengen hebben een zekere verkleuring ondergaan. In die gezamenlijke verkleuring is een duidelijk patroon herkenbaar, dat tot een nadere profilering uitnodigt, met enerzijds de noodzaak tot afgrenzing en anderzijds de mogelijkheden voor uitbouw in de gekozen richtingen. Het onderzoek van de vakgroep kan dan beschreven worden volgens een drietal onderzoeksrichtingen. $\mathrm{k}$ zal in miin betoog vooral ingaan op deze drie richtingen, terwijl Harm Kuipers straks bij zijn beschrijving van het onderzoek vooral aandacht zal besteden aan de thema's die vanuit deze richtingen kunnen worden benaderd.

De drie invalshoeken voor het onderzoek binnen de vakgroep zijn (wederom in alfabetische volgorde):

a. Bewegingssturing met een nadruk op de oog-hand-coördinatie, de effecten van inspanning (als parameters van vermoeidheid) op de bewegingssturing.

b. Biomechanica: modelvorming met behulp van zogenaamde mengselmodellen (ik kom daar aanstonds nog op terug) om tijdsafhankelijk gedrag van weefsels (bindweefsel, spienweefsel, tussenwervelschijf) te beschrijven in relatie tot hun mechanische belasting, en de experimentele toetsing van deze modelvoorspellingen.

c. Inspanningsfysiologie: het functioneren van de skeletspier, de hormonale regulatie van de output van de skeletspier in relatie tot belastingsniveau's, de structurele gevolgen van (te) grote belasting, effecten van training d.m.v. fitness-programma's. 
Deze drie richtingen, die elk op zich sterke wortels hebben in hun disciplines van herkomst, beschikken daarnaast over goede mogelijkheden voor een onderlinge vervlechting. Bovendien past het op deze wijze geprofileerde onderzoek goed binnen de contouren van de Faculteit der Gezondheidswetenschappen, omdat de maatschappelijke relevantie van het onderzoek zich vooral richt op vragen rond "gezond bewegen".

Niet de vragen naar de gevolgen van overbelasting op zich, noch de vraag naar behandeling van de schade staan hierbij centraal, maar veel meer de vraag naar de bandbreedte van een normale belasting en dus naar het punt waarop belasting in overbelasting zal overgaan. Qualitv of life is daarmee een belangrijk richtpunt voor de maatschappelijke betekenis van het onderzoek. Gezond bewegen, een kwestie van kwaliteit!

Het is duidelijk dat deze benadering tevens waardevolle aanknopingspunten biedt bij de geneeskundige problematiek rond de gevolgen van overbelasting en de behandeling daarvan. Deze spitsen zich dan ook en vooral toe op preventieve aspecten. Harm Kuipers zal daar straks nog meer over zeggen. Dit betekent, dat er een breed raakvlak bestaat tussen het onderzoek dat in beide faculteiten gericht is op bewegen en op het bewegingsapparaat. Dit blijkt overigens ook wanneer men de samenwerking van de vakgroep bewegingswetenschappen met andere vakgroepen in beide faculteiten bekijkt.

Binnen deze drie onderzoeksrichtingen zal het accent veeleer op diepte-investering dan op een grote schakering van vraagstellingen gelegd worden. Daarnaast streeft de vakgroep er naar om binnen dit interdisciplinaire onderzoekprogramma grote aandacht te besteden 
aan de mogelijkheid om de verschillende richtingen door interne dwarsverbanden te verbinden. Vanuit deze stevige operatiebasis kan dan externe samenwerking aangegaan worden. Van belang is daarbij, dat deze operatiebasis strategisch zo gekozen wordt, dat de grootst mogelijke flexibiliteit voor het aangaan van deze contacten gewaarborgd is. Dat zal overigens naar mijn mening alleen het geval zijn wanneer die operatiebasis zoals op grond van dit woordgebruik te verwachten is, ook voldoende fundamenteel is en er volgens een langer lopend programma gewerkt kan worden. Fundamenteel is dan niet alleen moleculair-genetisch. De beschrijving en analyse van het complexe mechanische gedrag van levende weefsels is niet minder fundamenteel. Met een knipoog naar de moleculair-biologen kan daar overigens bij gezegd worden, dat zulk onderzoek ook de kant op koerst van een verklaring op basis van het gedrag van complexe macromoleculen. Dus toch wel weer moleculaire biologie, zij het in een wat andere setting. I $\mathrm{k}$ wil dit aan de hand van een voorbeeld wat nader uitwerken.

\section{Moleculaire biomechanica}

Wij bestaan 'aan het begin van ons leven voor ongeveer negentig procent uit water. Wanneer wij na de bloei van ons leven gaan verdorren bevatten we toch nog steeds zo'n zestig procent water. Zijn wij dan lopende drilpuddingen? Wanneer we dat epitheton al verdienen, dan ligt dat niet zo zeer aan het water, maar veeleer aan het vet. Dat komt omdat de drilpudding die wij lijken te zijn constructief van zeer bijzondere aard is. Met een technische term kan deze constructie beschreven worden als een vezelversterkte pudding, opgesloten in 
wederom vezelversterkte compartimenten. Inderdaad, dat is het basisrecept van deze constructie: vezels en pudding. En iedere kok weet dat ook: wanneer de pudding toebereid moet worden, dienen eerst de vezels opgelost te worden.

Die grote hoeveelheid water, dat alom aanwezige transportmedium, tegelijkertijd medium voor onze biochemische werkplaats en de mechanisch onmisbare component in de hydraulische druksystemen van ons lichaam, is opgeslagen in enorme aggregaten van zogenaamde proteoglycanen, dat zijn grote koolhydraat-eiwitverbindingen ${ }^{(3)}$. Deze werkelijk reusachtige molecuulcomplexen, die ook met behulp van het elektronenmicroscoop zichtbaar gemaakt kunnen worden, gedragen zich als sponsen, die een grote hoeveelheid water opzuigen en het water bovendien vasthouden. Zij laten zich in tegenstelling tot de in het huishouden gebruikte sponsen slechts met de allergrootste moeite leeg knijpen.

Aan die vasthoudende eigenschap ontlenen zij hun biologische mechanische betekenis. Zo'n vezelversterkt hydraulisch druksysteem is in staat om werkelijk grote drukkrachten te weerstaan en door te leiden. Onze tussenwervelschijven illustreren dat op overtuigende wijze. Schattingen van de krachten die onder extreme omstandigheden door de lendentussenwervelschijf L5/S1 doorgeleid moeten worden vermelden waarden tot 8000 Newton, oftewel zo'n 800 kilo. Dat zou dicht bij de bezwijkgrens van het aangrenzende wervellichaam komen.

Hoe zit dat dan met bot? Ook bot is uiteraard een bij uitstek drukstijf materiaal, maar het heeft daarnaast in tegenstelling tot de tussenwervelschijf ook nog een hoge buigstijfheid. Het wordt dan ook op andere plaatsen van het lichaam ingebouwd. Maar ook bot is in essentie een vezelversterkt materiaal op basis van dezelfde componen- 
ten. Alleen bevat de spons nu naast water ook nog een hoog gehalte aan mineralen, d.w.z. er zijn kalkzouten in neergeslagen. Kunnen we dan nog wel van materialen spreken? Of gaat het hier eigenlijk om een soort constructies op macromoleculair niveau, die hun bijzondere "materiaaleigenschappen" juist ontlenen aan het gedrag van deze constructies? Waarom nu dit hele verhaal?

\section{Biomechanica en inspanningsfysiologie}

In de eerste plaats omdat op dit moleculaire niveau de biomechanica van zachte weefsels en de inspanningsfysiologie elkaar ontmoeten. Het geheim van de grote aantrekkingskracht van de grootmoleculaire sponsen voor water schuilt namelijk in het gigantische aantal negatieve electrische ladingen, die op de sponsdraden voorkomen. Deze overwegend negatieve ladingen trekken positieve ionen aan die met het water binnen gebracht worden. Electrostatische verschijnselen zijn dus van grote betekenis voor het mechanisch gedrag van deze weefselcomponenten. Dat betekent dat dit materiaal, om dat woord dan toch maar weer eens te gebruiken, ook gevoelig is voor de zuur-base-verhoudingen in het interne milieu. Bij spierarbeid komt melkzuur vrij en wanneer dat niet tijdig kan wcrden weggewerkt treedt verzuring op. Die verzuring van het interne milieu kan uitgroeien tot een ernstige bedreiging voor de celstofwisseling, leidend tot beschadiging van de weefsels, maar deze verzuring zal door zijn invloed op de ionen-verhoudingen binnen de proteoglycaan-aggregaten ook de mechanische eigenschappen van de weefsels niet ongemoeid laten. 


\section{Mengselmodellen}

In de tweede plaats kan met dit voorbeeld geillustreerd worden hoe fundamenteel de samenwerking van onze vakgroep met de Technische Universiteit in Eindhoven is. Op dit punt sluit het onderzoek namenlijk zeer goed aan bij verwant basaal onderzoek van de vakgroep Fundamentele Werktuigkunde. In de samenwerking met de TUE wordt door onze vakgroep medewerking verleend aan de uitbouw van het commerciële rekenprogramma DIANA van TNO. Het DIANAprogramma is één van de zeer geavanceerde rekenprogramma's waarmee zogenaamde mengselmodellen kunnen worden doorgerekend. Zo'n mengselmodel, ook wel meerfasenmodel genoemd, beschouwt het te modelleren materiaal in wezen als een mengsel van vaste en vloeibare componenten. De zoëven beschreven sponsen laten zich daarom zeer goed met zo'n mengselmodel beschrijven.

Door onze medewerker Hans Snijders is in het kader van de modellering van de tussenwervelschijf aan het mengselmodel een essentiële uitbreiding gegeven, zodat dit nu ook de zojuist beschreven electrostatische verschijnselen in rekening brengt. Daarmee wordt meer recht gedaan aan de bijzondere relatie die er tussen de grootmoleculaire spons en het door de spons opgezogen en vastgehouden water bestaat.

Omdat ook spierweefsel opgevat kan worden als een vezelversterkte constructie gevuld met een zeer bijzonder grootmoleculair systeem dat ingebed is in water, leent ook dit zich voor de zojuist beschreven wijze van modelleren. Dat levert nog een tweede snijpunt op tussen de biomechanica van zachte weefsels en inspanningsfysiologie, zoals blijkt uit de samenwerking op dit gebied tussen onze 
vakgroep en de vakgroep Biofysica in een project van het programma Hart en Vaten. Het is bovendien duidelijk dat hier ook een mogelijke aansluiting ligt bij het opgerichte Instituut voor Biomaterialen.

\section{Andere aanknopingspunten}

Ik heb in het voorgaande één voorbeeld uitgewerkt. Voorbeelden van andere interessante aanrakingsvlakken met geneeskunde zijn: het onderzoek naar bewegingssturing in onze vakgroep dat een relatie heeft met het onderzoek van de vakgroep KNO, maar dat ook van belang kan zijn voor verschillende projecten gericht op de verouderingsproblematiek. De coördinatie tussen oog en hand is gebaseerd op een uiterst subtiel sturingsmechanisme en in de vakgroep bestaat er expertise in het opsporen van beginnende stoornissen in deze coördinatie via gevoelige methoden. Voor de biomechanica bestaan er nog aanknopingspunten bij het onderzoek van de fysiotherapie, orthopaedie, revalidatie en reumatologie. In dit opzicht wil ik ook wijzen op de nieuwe mogelijkheden, die de pas gestarte doorstroomopleiding Bewegingswetenschappen voor Fysiotherapeuten biedt.

Voor de inspanningsfysiologie kunnen tenslotte aanknopingspunten genoemd worden met onderzoek naar diabetes type II, voorts bij de pathofysiologie van congenitale spierziekten, terwijl er tenslotte via de calcium-huishouding ook een raakvlak met het probleem van osteoporose bij veroudering gevonden kan worden.

Daarmee zijn we weer terug bij het multidiscplinaire netwerk van bewegingsonderzoek. Harm zal in zijn betoog laten zien dat alle drie invalshoeken, die ik reeds eerder in de loop van mijn uiteenzetting heb 
genoemd, inderdaad mogelijkheden bieden voor de ontwikkeling van waardevolle projectclusters van basaal onderzoek in relatie met zowel fundamenteel als toegepast klinisch en ander toegepast onderzoek.

\section{Bewegingsonderzoek en de geldmarkt}

Een aantal van deze ontwikkelingskernen bieden wellicht goede kansen op de $3 e$ geldstroom-markt. In dit opzicht moeten echter bij de maatschappelijke en commerciële relevantie van bewegingsonderzoek nog de volgende kanttekeningen gemaakt worden.

Het blijkt helaas ook moeilijk om voor dit onderzoek externe financiering te vinden. Sterke commerciële sponsors met een traditie om medewerking en steun te verlenen aan fundamenteel bewegingsonderzoek zijn schaars. Daaraan ligt waarschijnlijk een maatschappelijke prioriteitsbeleving ten grondslag. Aandoeningen van het bewegingsapparaat kunnen weliswaar ernstig afbreuk doen aan de kwaliteit van het leven, maar zij zijn bijna nooit (acuut) levensbedreigend. Deze maatschappelijk bepaalde randvoorwaarden hebben ertoe geleid dat bewegingsonderzoek nog steeds een achterstand heeft. Zolang er geen veranderingen in deze algemeen geldende situatie optreden zullen, naar ik vrees, ook kortdurende stimulaties helaas slechts een zeer beperkt effect sorteren.

\section{Bewegen en de fysische leefomgeving}

Sprekend over de maatschappelijke context waarin bewegingsonderzoek plaats vindt wil ik nog een paar woorden wijden aan 
bewegen en het fysische woon- en werkmilieu. Ik formuleer het met opzet wat vaag, want het omvat meer dan puur ergonomische aspecten. Niet voor niets gebruikte ik de term "quality of life", en het gaat dan ook om het totale kader waarin wij wonen, werken en ons ontspannen.

De mens is niet langer meer de jager, die door behendigheid en snelheid in zijn levensonderhoud moest voorzien. Werd zijn actieradius door de ontwikkeling van de landbouw al kleiner, door de industrialisatie nam die nog verder af, waarbij de bestuursindustrie bepaald niet achter bleef. Steeds meer werd onze "actieve" samenleving een staande en vooral zittende samenleving: een chair-bound society. Tevens werd de afstand tussen gebruiker, ontwerper en producent steeds groter, zodat de fysieke en perceptief-cognitieve inrichting van onze woon- en werkomgeving voor wat er aan handelings- en bewegingsruimte over bleef, steeds minder goed afgestemd dreigde te raken op behoeften en mogelijkheden van de gebruiker. Ook het belang van gezond bewegen werd steeds meer vergeten. Dat leidde tot de herontdekking van de "human factor" in het werk en de werkomgeving.

Dat leidde er toe dat binnen de gezondheidszorg de sector arbeidsgezondheidszorg zich ontwikkelde, binnen de regelgeving leidde het tot de komst van de ARBO-wetgeving en in interactie met de techniek leidde het tot de ontwikkeling van ergonomisch gefundeerde normen en ontwerpregels. Drie verschillende invalshoeken: één vanuit de gezondheidszorg, één vanuit de randvoorwaarden scheppende en regelgevende overheidstaak en één technische invalshoek met respectievelijk een vooral medische, administratief-juridische en technische inkleuring. Het probleem is zo complex dat bovendien door talloze 
andere deskundigen een bijdrage voor de oplossing ervan wordt geleverd. Ik denk dan aan arbeidshygiene, epidemiologie, microbiologie, toxicologie om er enkele te noemen en aan onderdelen van de gedrags- en maatschappijwetenschappen.

Door de toenemende vergrijzing van onze bevolking heeft het probleem bovendien nieuwe dimensies gekregen. De vraag "hoe wij onze ouder wordende burgers in een goede conditie en op een gezonde wijze aan het werk kunnen houden" is om macro-economische redenen steeds klemmender geworden. Daarbij wordt de aandacht vaak ten onrechte te veel gericht op de kunstmatige grens tussen deelname aan het werk en de leeftijdsgebonden beëindiging ervan. Er bestaat geen biologische, alleen een administratief-juridische grens. Alleen wanneer aan het totale traject van het werkzame leven van de ouder wordende burger aandacht wordt besteed, en alleen wanneer aan het totaal van de relevante randvoorwaarden voor een optimale woon- en werkomgeving aandacht wordt geschonken kan aan dit complexe probleem recht gedaan worden. Een betere werkomgeving voor ouderen is meestal ook een betere werkomgeving voor iedereen.

Ik verwacht dat ook de bewegingswetenschappen hier een waardevolle bijdrage kunnen leveren. Niet voor niets heb ik zojuist de nadruk gelegd op de krimpende leefruimte van de moderne mens, die niet gecompenseerd wordt door een steeds groter massatoerisme op lange afstand, noch door de toenemende massale dagelijkse verplaatsingen van werknemers. De belangstelling voor de ontwikkeling van fitness-programma's (van bedrijfsfitness tot en met huisvrouwen- en bejaardengymnastiek) wijst op de herkenning van de risico's van onze toegenomen bewegingsarmoede, met overigenns alle gevaren voor het 
ontstaan van commerciële wildgroei ${ }^{(4)}$. Het ontwikkelen van verantwoorde bewegingsprogramma's vergt een grondige kennis van bouw en functie van het bewegingsapparaat. Wanneer daaraan ook een leeftijdsafhankelijke dimensie meegegeven moet worden dan heeft de bewegingswetenschapper zijn handen vol aan de fysieke aspecten van het bewegen. Dat er intussen veel meer aan de hand is staat boven elke twijfel. Gezond bewegen bij het werk en in de vrije tijd heeft ook sociaal-culturele kanten. Dat betekent dat bij de toepassing in het maatschappelijke veld deskundigen die over een grondige kennis van de fysieke aspecten van het bewegen beschikken zullen moeten samenwerken met deskundigen, die over een niet minder gedegen kennis beschikken van de gedrags- en maatschappijwetenschappelijke aspecten.

Al deze aspecten zijn ieder voor zich zo wezenlijk voor dit vraagstuk, maar tegelijkertijd ook zo complex, dat het naar mijn stellige overtuiging geen goede zaak is om deze allemaal binnen één onderzoek- en onderwijsprogramma onder te brengen. Dan dreigt aan de gedegen opbouw van de noodzakelijke specifieke deskundigheid afbreuk gedaan te worden. Differentiaprogramma's zijn echter heel goed denkbaar. Het betekent dat voor de opleiding bewegingswetenschappen het accent op de natuurwetenschappelijke aspecten van het fenomeen bewegen zal moeten vallen, maar tegelijkertijd moet ervoor gezorgd worden dat het opleidingsprogramma een gevoeligheid voor en zicht op de gedrags- en maatschappijwetenschappelijke facetten -pbouwt. 


\section{Het onderwijs}

Ik heb over het onderwijs nog niets gezegd. Dat betekent niet dat dat niet mijn warme belangstelling zou hebben, noch dat ik er geen mening over zou hebben. Integendeel, ik acht het een voorrecht om nog een aantal jaren actief betrokken te zijn in het voor ons land unieke probleem-georiënteerde onderwijs dat aan de RL werd ontwikkeld. Het heeft steeds mijn warme belangstelling gehad. Ik heb intussen al heel wat discussies erover achter de rug en Harm Kuipers zal aan dit onderwerp in zijn toespraak speciale aandacht besteden.

\section{Tot besluit}

Meneer de Rector, geachte toehoorders, met mijn mede-orator heb ik afgesproken, dat wij de lengte van onze spreektijd zouden afstemmen op de spanningsboog van Uw aandacht. Dat betekent dat ik nu zo zoetjes aan aan het einde van mijn verhaal ben gekomen. Ik zie de toekomstige samenwerking met de leden van onze vakgroep, en samen met hen ook de komende samenwerking met velen van $\mathrm{U}$ in het netwerk van het Maastrichtse onderzoek en onderwijs met groot vertrouwen tegemoet. Allen die mij bij het oppakken van deze taak behulpzaam zijn geweest wil ik daarvoor danken en ik ben het bestuur van deze instelling zeer erkentelijk voor het vertrouwen dat zij blijkens deze benoeming in mij hebben gesteld.

Wanneer gezond bewegen een kwestie van kwaliteit is, zou $\mathrm{U} \mathrm{nu}$ de gelegenheid geboden moeten worden om $U$ enkele ogenblikken te vertreden. Omdat dit echter het protocol al te zeer geweld zou aandoen, zullen we dit moeten uitstellen tot over een half uur. Alleen de 
rector, mijn mede-orator en mij is het gegund voor een korte wijle in beweging te komen.

Ik dank $U$ voor Uw aandacht. 



\section{BEWEGINGSWETENSCHAPPEN, EEN KWESTIE VAN KIEZEN}

rede uitgesproken bij de aanvaarding van het ambt

van hoogleraar in de Bewegingswetenschappen

Faculteit der Gezondheidswetenschappen

van de Rijksuniversiteit Limburg

op donderdag 29 oktober 1992

door

dr. H. Kuipers 

Meneer de rector, leden van de universitaire gemeenschap, zeer geachte toehoorders,

\section{Profiel van Bewegingswetenschappen in Maastricht}

De studierichting BewegingsWetenschappen (BW) is nog betrekkelijk jong en ondergebracht bij de Faculteit der Gezondheidswetenschappen (FdGW). De keuze om een dergelijke studierichting te ontwikkelen komt o.a. voort uit een besef dat bewegen en lichamelijke aktiviteit niet alleen een wijze van vrijetijdsbesteding is, maar dat bewegen kan bijdragen aan het in stand houden en bevorderen van de gezondheid. Voorts kan regelmatige fysieke aktiviteit een belangrijke bijdrage leveren aan de preventie van welvaartsziekten als hart- en vaatziekten, type II diabetes, obesitas en osteoporose Het is in dit verband opmerkelijk dat zowel in ons land als vele landen om ons heen, thans nog aanmerkelijk meer geld besteed wordt aan de behandeling van deze ziekten dan aan preventie er van. Dat, terwijl de meeste winst in termen van kostenbesparing, te halen is uit preventie. Voorts is bewegen een belangrijk middel om de mobiliteit en zelfstandigheid bij ouderen in stand te houden, waardoor het bijdraagt aan de kwaliteit van het leven. Beweging kan voorts als ondersteuning van de therapie gebruikt worden bij verschillende vormen van revalidatie.

Ondanks dat er verschillende gunstige effekten van beweging blijken te zijn, is er toch nog relatief weinig onderzoek naar de relatie tussen beweging en gezondheid verricht. Het is nog geenszins duidelijk of regelmatige beweging jaren aan het leven toevoegt. Het is wel duidelijk dat beweging leven aan de jaren toevoegt. Er ligt nog een groot onontgonnen gebied, dat de moeite waard is in cultuur te brengen. 
Een studierichting BW biedt de mogelijkheden om daaraan een bijdrage te leveren.

Wat verstaan we in Maastricht onder de studie BewegingsWetenschappen (BW)? We kunnen BW zien als een studie die zich bezig houdt met de relatie tussen lichamelijke aktiviteit en gezondheid. Met lichamelijke aktiviteit bedoelen we alle vormen van bewegen: oefening in het kader van revalidatie en therapie, beweging bij het werk, het uitvoeren van dagelijkse dingen, recreatief bewegen en sport. Omdat bewegen van verschillende invalshoeken wordt onderzocht is gekozen voor een vakgroep met een multidisciplinaire samenstelling. Vanuit de vakgroep $B W$ bestaan er verschillende relaties met vakgroepen van de Faculteit der Geneeskunde (FdG) en de Faculteit der Gezondheids Wetenschappen (FdGW), maar ook met instellingen buiten de universiteit. Wat dit laatste betreft moet de samenwerking met de Technische Universiteit Eindhoven (TUE) en het Instituut voor Revalidatie Vraagstukken (IRV) in Hoensbroek genoemd worden.

Zo'n ruime omschrijving van BW vraagt ook om inperking en profilering. Het profiel van een BW-er die in Maastricht opgeleid wordt, willen we omschrijven als een academicus met een vooral natuurwetenschappelijke achtergrond, die hem/haar in staat stelt zelfstandig onderzoek te doen naar de relatie tussen lichamelijke aktiviteit en gezondheid. Het onderzoek kan zowel toegepast als basaal wetenschappelijk van aard zijn. Ofschoon de BW-er gedragswetenschappelijke kennis moet bezitten, ligt zijn specifieke kennis en vaardigheid op het terrein van het natuurwetenschappelijke onderzoek. De BW-er moet daarnaast in staat zijn onderwijs te geven betreffende de relatie tussen beweging en gezondheid, terwijl ook beleidsfuncties tot zijn competentie behoren. 


\section{ONDERZOEK}

Bij het onderzoek van de vakgroep BW staat steeds de relatie tussen beweging en gezondheid centraal. Anders gezegd, hoe gezond zijn bewegen en sportbeoefening en waar ligt de grens tussen belasting en overbelasting? Het onderzoek dat thans door de leden van de vakgroep wordt verricht is zowel toegepast als meer fundamenteel van aard. De bestaande onderzoeksthema's moeten verder worden uitgebouwd, waarbij het ons voor ogen staat om niet alleen de onderlinge samenhang te intensiveren maar ook om de bestaande banden binnen en buiten de universiteit te versterken. Als we, uitgaand van het huidige onderzoek van de vakgroep, een discipline overstijgende indeling naar mogelijke thema's maken, kunnen de volgende thema's worden onderscheiden:
a) de relatie tussen lichamelijke aktiviteit en gezondheid
b) therapeutische en biologische effecten van fysiotherapie
c) bewegen en revalidatie

\section{De relatie tussen lichamelijke aktiviteit en gezondheid}

Lichamelijke inspanning veroorzaakt een groot aantal aanpassingen in het lichaam, die tot een beter lichamelijk funktioneren leiden en een positieve invloed op de gezondheid hebben. Het is echter niet zo dat men steeds gezonder wordt naarmate men meer beweegt. Er zijn grenzen aan het aanpassingsvermogen van het lichaam. Wanneer deze grenzen worden overschreden spreken we van overbelasting. Betreft overbelasting de spier dan ontstaat spierschade, welke zich o.a. uit in spierpijn. Een deel van het onderzoek binnen de vakgroep BW is 
gericht op de vraag in hoeverre skeletspieren zich kunnen aanpassen aan functionele eisen en welke faktoren een rol spelen bij het ontstaan van overbelasting. Dergelijk onderzoek is nuttig omdat de skeletspier thans voor andere doeleinden wordt gebruikt, zoals voor de ondersteuning van het zieke hart en ter vervanging van sluitspieren van anus en blaas. Ongetwijfeld zullen in de nabije toekomst andere toepassingen worden gevonden. De mensen van de TUE kunnen met hun modelmatige benadering aan het skeletspieronderzoek een extra dimensie toevoegen.

Overbelasting kan ook een meer algemeen karakter hebben en dit is een situatie die in de topsport overtraining wordt genoemd. Wat onstaansmechanisme en symptomatologie betreft is er grote overeenkomst met wat we in het dagelijkse leven overspannen of overstressed noemen. Gegevens die bij sporters worden verkregen kunnen daardoor van nut zijn voor het vergroten van ons inzicht in de mechanismen die in het alledaagse leven tot mentale overbelasting kunnen leiden.

Het onderzoek naar de relatie tussen bewegen en gezondheid is ook belangrijk bij het ouder worden, omdat onze bevolking in snel tempo vergrijst. Thans telt de Nederlandse bevolking ongeveer 1.8 miljoen mensen boven de 65 jaar en in het jaar 2000 wordt dit aantal geschat op 2.2 miljoen. Het aantal hoogbejaarden boven de 80 jaar zal van $12 \%$ van alle bejaarden thans tot 23 a $25 \%$ stijgen in het jaar 2000 . In het algemeen moet geconstateerd worden dat in de meeste insteilingen voor bejaarden een overwegend zittend bestaan wordt geleid en dat lichamelijke aktiviteit of onvoldoende of in het geheel niet wordt gestimuleerd. Fysieke inactiviteit versnelt de achteruitgang van het lichamelijk funktioneren en dit zal de verzorgingsbehoefte doen toene- 
men. Een klein voorbeeld. Een afname van bijvoorbeeld de kracht in de bovenbenen maakt het moeilijk om uit een stoel te komen of een trap op te lopen. Dergelijke aktiviteiten worden vervolgens zo veel mogelijk vermeden, waardoor de achteruitgang in de hand wordt gewerkt. Door relatief eenvoudige oefeningen en adviezen kunnen de spieren van de bovenbenen op kracht worden gehouden, waardoor de zelfredzaamheid beter behouden blijft. Het zou goed zijn om van overheidswege een aktief beleid te voeren, dat gericht is op het zo veel en breed mogelijk stimuleren van beweging. Hierbij moet beweging in de meest brede zin worden gestimuleerd, onder het motto "beter iets dan niets". Het is daarbij belangrijk de bewegingsvormen aantrekkelijk te maken door aan te sluiten bij de mogelijkheden en wensen van de mensen. Onderzoekingen tonen aan dat bejaarden veelal tot meer in staat zijn dan menigeen denkt $(2,7)$. In een beleid dat gericht is op het stimuleren van beweging past ook het advies om in bejaardenoorden niet alleen een recreatieruimte, maar ook een ruimte voor lichamelijke activiteit in te richten. Er moeten, op de individuele mogelijkheden en behoeften afgestemde programma's worden ontwikkeld en hier ligt een potentieel werk- en onderzoeksgebied voor bewegingswetenschappers.

Veroudering gaat helaas vaak gepaard met een aantal ziekten en afwijkingen. Voor de aanwezige deskundigheid binnen de vakgroep BW en voor aansluiting bij andere onderzoeksthema's binnen de RL zijn met name diabetes type II, hart- en vaatziekten en afwijkingen aan het bewegingsapparaat relevant. Voorzichtige schattingen voorspellen dat er in het jaar 2005 in totaal 340.000 diabeten zullen zijn (8). Ongeveer $90 \%$ hiervan heeft type II of ouderdomsdiabetes. Diabetes heeft een negatieve invloed op de risikofaktoren voor hart- en vaatziekten en 
beweging kan als secundaire preventie dienen om de nadelige gevolgen van de ziekte te beperken. Er zijn voorts aanwijzingen dat weinig beweging als een aparte risikofaktor voor diabetes type II (4) en ook voor hart- en vaatziekten kan worden beschouwd (3).

Bij type II diabetes is sprake van een verminderde insulinegevoeligheid. Insulinegevoeligheid kan in gunstige zin beïnvloed worden door gewichtsreductie, goede voeding en lichamelijke aktiviteit (5). Het is uit de inspanningstysiologie bekend dat de skeletspier een belangrijk doelorgaan is voor insuline en dat lichamelijke aktiviteit de insulinegevoeligheid verhoogt. Van de mogelijkheid om beweging te gebruiken voor primaire preventie en behandeling van diabetes type II wordt in de geneeskunde nog nauwelijks gebruik gemaakt.

Andere met veroudering gepaard gaande problemen zijn klachten van het bewegingsapparaat. Onderzoek van het bewegingsapparaat is maatschappelijk uiterst relevant. Klachten van gewrichten, spieren, banden en pezen, ook wel samengevat onder de verzamel-. naam "rheumatische ziekten", worden in Nederland gevonden bij ongeveer 3 miljoen mensen. Hiervan zoeken 450.000 medische hulp. Van alle mensen die de huisarts consulteren doen $15-20 \%$ dit vanwege rheumatische klachten. Een belangrijk deel van deze klachten, vooral bij ouderen, berust op arthrose. De oorzaken van arthrose zijn nog niet geheel bekend. Het idee dat zware belasting van gewrichten, zoals bij topsport eerder tot arthrose leidt, wordt door onderzoek tegengesproken. Toch lijkt een nog niet geheel afgerond onderzoek in de VS er op te wijzen dat er wat betreft het bewegingsapparaat grenzen aan gezond bewegen zijn. Een vergelijkend onderzoek tussen ex-topsporters en weinig aktieve mensen wijst er op dat de ex-topsporters meer klachten en afwijkingen van het bewegingsapparaat hebben dan de 
weinig sportende mensen (Costill, persoonlijke mededeling). Deze gegevens kunnen waarschijnlijk worden doorgetrokken naar mensen die beroepsmatig zware inspanning verrichten. Het onderzoek dat de vakgroep thans in relatie tot rheumatische ziekten doet, richt zich met name op de invloed van leeftijd op de mechanische eigenschappen van de tussenwervelschijf. De deskundigheid binnen onze universiteit en de aanwezige infrastructuur bieden goede mogelijkheden om dit onderzoek te versterken en uit te breiden.

Ook al is bewegen gezond, het kan niet voorkomen dat veroudering tot beperkingen van lichamelijke en geestelijke funkties leidt. Voor het vastleggen van defekten in mentale funkties en motorische vaardigheden, kan de binnen onze vakgroep aanwezige discipline funktieleer een nuttige inbreng hebben. Soms kunnen technische aanpassingen de fysieke beperkingen in meer of mindere mate compenseren. Op het terrein van dergelijke aanpassingen kan de samenwerking met de TUE en IRV verder gestalte krijgen en liggen er kansen voor het ontwikkelen van gerontechnologie en biomaterialen.

\section{Therapeutische en biologische effekten van fysiotherapie}

Een unieke kans die de studierichting BW in Maastricht geboden wordt, is het opzetten van onderzoek naar therapeutische en biologische effekten van fysiotherapie. Sinds september 1992 draagt de vakgroep $\mathrm{BW}$ bij aan een 2-jarige doorstroomopleiding fysiotherapie. Het doel van deze opleiding is om gediplomeerde fysiotherapeuten op te leiden tot onderzoeker. Het onderzoek betreft in eerste instantie vooral therapeutische effekten van fysiotherapie, terwijl er naar gestreefd wordt om ook onderzoek naar de biologische effekten op 
weefsel- en celniveau op te gaan zetten. Dergelijk onderzoek leidt naar verwachting niet alleen tot betere theorievorming als basis voor fysiotherapie, maar op grond van de resultaten van effektonderzoek kan ook de indicatiestelling worden verscherpt. Kennis over de effekten zal tevens de basis moeten zijn voor consensus over indicatiestelling en behandeling van fysiotherapie. Het is de verwachting dat dit op termijn tot kostenbesparing in de gezondheidszorg zal leiden.

\section{Bewegen en revalidatie}

Een onderzoeksgebied dat in Maastricht nog te weinig ontwikkeld is, maar waar potentiële mogelijkheden liggen is revalidatie. Samen met het Revalidatiecentrum Hoensbroek, het IRV, de TUE en de vakgroep $B W$ is overleg gaande over de vraag hoe het revalidatieonderzoek gestalte kan krijgen. Ofschoon BW zich in het verleden niet met hartrevalidatie heeft bezig gehouden, behoort ook een ontwikkeling in die richting zonder meer tot de mogelijkheden.

\section{Inpassing van het BW onderzoek in de matrixstructuur}

Het zal duidelijk zijn dat er voor de vakgroep vele mogelijkheden liggen om maatschappelijk en wetenschappelijk relevant onderzoek te doen. Tussen de genoemde thema's bestaan veel raakvlakken en daarnaast bestaan er verschillende aanknopingspunten met de bestaande onderzoeksthema's binnen de instelling. Het onderzoek van de vakgroep BW kan vooral een bijdrage leveren aan de thema's "veroudering", "voeding en toxicologie" en "hart- en vaatziekten". 
Een probleem waarmee de vakgroep thans wordt geconfronteerd is hoe het onderzoek binnen de instelling ingekaderd moet gaan worden. Om ongebreidelde vrijheid en versnippering van mankracht en middelen tegen te gaan heeft de universiteit gekozen voor een beperkt aantal onderzoeksthema's. Ingegeven door de opgelegde bezuinigingen vanuit den Haag is het beleid van de universiteit er op gericht om niet naar meer, maar juist naar minder onderzoeksthema's te streven. Het onderzoek aan de RL is georganiseerd in een zogeheten matrixstructuur. Daarbij heeft niet elke vakgroep zijn eigen, duidelijk afgeperkt onderzoek, maar de onderzoeksthema's staan centraal. Daardoor kan een vakgroep aan verschillende thema's meedoen, terwijl ook meerdere vakgroepen samenwerken binnen een bepaald thema. Deze organisatorische matrixstructuur is suksesvol gebleken voor multidisciplinair onderzoek. De matrix lijkt thans het verzadigingspunt te hebben bereikt, met dien verstande dat er nauwelijks nog mensen aan de bestaande thema's kunnen worden toegevoegd. Voor nieuwkomers is het daardoor moeilijk om alsnog een plaats in de matrix te verwerven. De verzadiging van de matrixstructuur is in belangrijke mate ingegeven door financiële beperkingen, die de universiteit krijgt opgelegd. Daardoor is moeilijk nieuwe ruimte te creëren voor nieuwe thema's, ook al zijn ze wetenschappelijk en/of maatschappelijk relevant. Het onderzoek van een deel van de stafmedewerkers van de vakgroep $\mathrm{BW}$ is daarom nog niet bij de bestaande thema's ondergebracht. Dit is een ongewenste situatie. Als er één plaats in Nederland is waar multidisciplinair onderzoek naar de relatie tussen beweging en gezondheid gestalte zou kunnen krijgen, dan is het wel Maastricht. Een van de mogelijke opties is om het onderzoek op te delen over de verschillende hoofdthema's zoals bijv. bij "Voeding", "Veroudering" en "Hart- en Vaatziek- 
ten". Een nadeel van een dergelijke opsplitsing is dat wetenschappelijke kontakten zullen verminderen en dat de herkenbaarheid van het stuk onderzoek naar de relatie bewegen en gezondheid als zodanig verloren gaat. Door de vakgroep, de faculteit en de universiteit zullen er ten aanzien van genoemde problematiek, op niet al te lange termijn, keuzes gemaakt moeten worden.

Om de gesignaleerde verstarring van de matrixstructuur tegen te gaan en flexibel op nieuwe ontwikkelingen te kunnen inspelen, moet het bestuur van de universiteit kunnen sturen. Aan de hand van de 5-jaarlijkse evaluatie van de interfacultaire wetenschaps commissie zou iedere 5 jaar opnieuw bekeken kunnen worden, of de gekozen programma's in al haar onderdelen nog relevant en produktief zijn en of bepaalde ontwikkelingen een verschuiving van middelen en menskracht wenselijk maakt.

\section{ONDERWIJS}

Naast het doen van research behoort het verzorgen van onderwijs tot de primaire taken van de vakgroep. Als bevoegd onderwijzer heb ik een meer dan gemiddelde belangstelling voor onderwijs en wil er daarom enige woorden aan wijden.

\section{Probleem Gestuurd Onderwijs}

We hebben als universiteit de maatschappelijke verantwoordelijkheid om mensen op te leiden die een zo groot mogelijke slaagkans hebben op de arbeidsmarkt en dit vraagt een opleiding die kwalitatief aan hoge eisen voldoet. De onderwijsvorm die de Rijksuniversiteit 
Limburg ( $R L$ ) in Maastricht heeft gekozen, is onderwijs volgens het Probleem Gestuurd Onderwijs (PGO) model. In het PGO model worden geen aparte vakken gedoceerd, maar wordt de stof geïntegreerd en uitgaande van praktische problemen of vragen aangeboden. Deze problemen worden in groepjes van 8-10 studenten, de zogeheten onderwijsgroep (OWG), en onder het toeziend oog van de tutor, besproken. Elke OWG komt twee keer per week bijeen en aan de hand van de aangeboden problemen worden studiedoelen geformuleerd en besproken. Er wordt daarbij een groot beroep gedaan op de zelfwerkzaamheid van de studenten. De rol van de docent als tutor is vooral die van begeleider (6).

Het PGO systeem heeft een aantal belangrijke voordelen ten opzichte van het klassieke, als aparte vakken gedoceerde onderwijs (6). Dat heeft onder meer tot gevolg, dat ook andere universiteiten binnen en buiten Nederland gebruik gaan maken van elementen van het PGO. Maastricht moet er daarom voor waken om de huidige voorsprong ten opzichte van andere instellingen niet te zien veranderen in een achterstand. We moeten er alles aan doen om niet alleen de sterke kanten van het PGO uit te bouwen, maar ook oog te hebben voor de minder sterke aspecten van het systeem. Ofschoon kritiek op het PGO vaak als reactionair en bedreigend wordt beschouwd, staat in het oerstuk van de universiteit, "de basisfilosofie" uit 1972 (1) dat er voortdurend ruimte moet zijn voor vernieuwing en bijstelling van het onderwijssysteem. Het is nuttig om daarbij gebruik te maken van de ervaringen van enkele buitenlandse instellingen, waar eveneens onderwijs op PGO basis wordt gegeven. Er zullen ook wat onderwijs betreft keuzes gemaakt moeten worden. 
Vanwege het werken in kleine groepen, elk onder begeleiding van een tutor, is het PGO aanzienlijk arbeidsintensiever dan het frontale, op colleges gebaseerde onderwijs. Ten opzichte van andere universiteiten geeft dit bij de $\mathrm{RL}$ een ongunstige verhouding tussen onderwijs en onderzoek. De FdGW gaat uit van 50\% onderwijs en $50 \%$ onderzoek. Dit is echter marginaal om onderzoek van voldoende omvang en kwaliteit te kunnen doen, zeker daar het bestuur van de faculteit de onderzoeksprestaties voortaan zwaarder gaat meetellen voor de toekenning van mankracht en middelen.

Wat de onderwijslast betreft is er binnen de FdGW ook nog verschil tussen vakgroepen. De FdGW heeft beslist dat vakgroepen met onderzoek dat door de wetenschapscommissie positief beoordeeld is, minder onderwijs mogen doen. Juist de groepen die het goed doen in het onderzoek, krijgen gemakkelijk gelden uit $2 e$ en $3 e$ geldstroom en kunnen nog meer onderzoek doen. Bovendien kunnen ze zich permitteren om bijvoorbeeld tutoren in te huren en hun daadwerkelijke onderwijslast daardoor nog verder te verlagen. Niet de gevestigde groepen, maar juist de jonge, groeiende vakgroepen zouden meer tijd voor onderzoek moeten krijgen.

\section{De onderwijsgroep en de rol van tutor}

Van het totaal aantal facultaire onderwijsuren wordt een belangrijk deel door de tutorrol ingenomen. Juist de invulling van de tutorrol wordt door velen ervaren als een taak die niet past bij het nivo, de kennis en de vaardigheden van de docent. Omdat de OWG en de tutorrol de hoekstenen van het Maastrichtse onderwijs vormen, is een herbezinning met betrekking tot het funktioneren van de OWG en de 
invulling van de tutorrol op zijn plaats. Mogelijkheden voor verandering zouden bijvoorbeeld kunnen zijn: verbetering van de kwaliteit en structuur van de studietaken, in de OWG meer accent leggen op het onderling overdragen van kennis en een andere invulling van de tutorrol, waarbij meer het accent komt te liggen op vakinhoudelijke inbreng.

Onderzoek heeft laten zien dat de OWG-en ook goed funktioneren met studenttutoren. De rol van de tutor is daarbij vooral een procedurele en het is de vraag of de OWG ook niet zonder tutor zou funktioneren. Om de juiste procedures en spelregels te bewaken moet de rol van gespreksleider dan meer inhoud krijgen. Dit kan in het eerste jaar aangeleerd worden. De tutor zou daartoe in het eerste jaar een wat andere rol kunnen krijgen dan thans het geval is. Hij dient er steeds aktief op toe te zien dat er duidelijke en relevante leerdoelen worden geformuleerd en dat de terugrapportage niet slechts het voorlezen is van aantekeningen, maar dat de studenten zich trainen in het helder uitleggen en presenteren van de gegevens in de onderwijsgroep. Dit is een goede training voor het toekomstig presenteren in vakkringen. Daarnaast moet de tutor de studenten trainen in het inhoud geven en goed vervullen van de rol van gespreksleider. De rol van gespreksleider rouleert en deze moet er voor zorgen dat de algemene omgangsregels in de groep juist worden gehanteerd en dat er duidelijke afspraken worden gemaakt. Dit is een goede voorbereiding op het leiden van vergaderingen en discussies in toekomstige banen. In het tweede jaar kan de tutorrol geheel door de gespreksleider worden overgenomen, terwijl de docent weer de rol van vakman krijgt. Dit kan bijvoorbeeld door na de onderwijsgroep, meteen vanaf het eerste jaar, alle groepen samen te laten komen met de voor die 
taak inhoudsdeskundige(n). Deze bijeenkomst heeft het karakter van een responsiecollege en geeft direkt terugkoppeling op de taak. Indien wenselijk kan de volgende studietaak worden ingeleid. Een dergelijke invulling van de tutorrol ondervangt ook de ongelijkheid dat gewoonlijk slechts een groepje van 8-10 mensen van de deskundigheid van een tutor kan profiteren.

Met een dergelijke aanpak zal de onderwijsbelasting aanzienlijk teruglopen. De vrijkomende tijd kan ten dele worden gebruikt voor inhoudelijke taken als het begeleiden van werkstukken, stages, verslagen en studiebegeleiding. De docent is op deze manier weer inhoudsdeskundig bezig en meer tijd voor inhoudelijke begeleiding van studenten zal tot een beter studierendement kunnen leiden.

\section{Het toetssysteem}

Ook aan het toetssysteem wil ik enkele woorden wijden. Volgens de filosofie die aan het PGO ten grondslag ligt wordt toetsgericht studeren door velen als ongewenst gezien. Geheel in lijn hiermee probeert men dit gedrag tegen te gaan door de studievoortgang te beoordelen met behulp van de VoortGangsToets (VGT). De BlokToets (BT), die na elk blok van 6 weken wordt afgenomen, had aanvankelijk een formatief karakter, alleen bedoeld om de student zeif te informeren over de studieprestaties. Binnen de FdGW wordt de BT thans ook gebruikt voor summatieve beoordeling van de studenten. Sommigen beweren dat dit in strijd is met het PGO principe, maar dat is onjuist. Een belangrijk onderwijskundig aspekt van toetsen, dat vrijwel nooit wordt genoemd, is dat een toets een belangrijke functie heeft bij de verwerking en verdieping van de leerstof. Ook in het PGO is herhalen 
de basis voor verwerking en verdieping en omdat de leerstof geïntegreerd wordt aangeboden zal het herhalen van een PGO blok meer verdieping geven dan het herhalen van een op zichzelf staand stuk leerstof, zoals in het klassieke universitaire onderwijs. Juist een bloktoets is een uitstekend middel om de stof van de afgelopen 6 weken te herhalen. Het is niet reëel te veronderstellen dat studenten voldoende intrinsiek gemotiveerd zijn om zonder extrinsieke prikkel na elk blok de stof intensief te herhalen.

Welke plaats heeft de VGT dan nog? Het verdient aanbeveling om na te gaan welke extra informatie de VGT geeft, naast de reeds verkregen gegevens uit de BT, verslagen en werkstukken. Gezien de investering in mankracht en middelen voor het produceren en beoordelen van de VGT lijkt deze aanbeveling relevant. Uit de resultaten moet men dan ook de nodige consequenties durven trekken. Indien de VGT geen extra informatie verschaft naast de reeds beschikbare gegevens, zou het bijvoorbeeld te overwegen zijn om de frequentie van de VGT te verminderen of geheel af te schaffen.

\section{Dankwoord}

Dat ik samen met collega Huson vandaag deze funktie kan aanvaarden zou niet mogelijk geweest zijn zonder het voorwerk en de bijdrage van anderen. Zonder iemand tekort te willen doen wil ik toch enkele namen noemen. Uit Maastricht zijn dit, in alfabetische volgorde, Jan Drukker, Foppe ten Hoor, Frans Verstappen en Ger van der Vusse. Vanuit Eindhoven heeft Jan Janssen veel bijgedragen aan de integratie van de technici uit Eindhoven en de biomedici uit Maastricht. Daarnaast is het aan de inzet van de leden van de vakgroep te danken dat 
er soms onder moeilijke omstandigheden een onderwijsprogramma werd ontwikkeld en onderzoek werd gedaan.

Met onze benoeming is voor de studierichting BW en de vakgroep BW een nieuwe fase ingeluid. Hopelijk is het een fase die gekenmerkt wordt door vooruitgang en bloei. Zowel wat het onderwijsprogramma als het onderzoekprogramma betreft, zullen belangrijke keuzes gemaakt moeten worden. Ik spreek de wens uit dat we over enkele jaren zullen kunnen zeggen dat het vooral een kwestie van goed kiezen is geweest. 
Referenties

1. Basisfilosofie, Maastricht 1972

2. Belaman MJ, GA Gaesser

Exercise training below and above the lactate threshold in the elderly. MSSE 23(5): 562-568, 1991

3. Bijnen, F.C.H. Nota "Lichamelijke inactiviteit, risicofactor voor hart- en vaatziekten". Utrecht, JJRC, 1990

4. Ekoe, JM. Overview of diabetes mellitus and exercise. Med. Sci Sports Exerc. 21: 353-355, 1989

5. Reaven GM. Banting lecture 1988: role of insulin resistance in human disease. Diabetes 37: 1595-1607, 1988

6. Schmidt, H.G., P.A.J. Bouhuijs: Onderwijs in taakgerichte groepen. Spectrum Utrecht, Antwerpen, 1980

7. Stamford, BA. Exercise and the elderly.

In: Pandolf (ed), Exercise and sport sciences reviews. Vol 16: 341-380. MacMillan Publishing Company, New York, 1988

8. Stuurgroep toekomstscenario's gezondheidzorg. Chronische ziekten in het jaar 2005. Deel 1, Scenario's over diabetes mellitus 1990-2005. Utrecht, Bohn, Scheltema \& Holkema, 1990 
Referenties tekst dr.A. Huson

1. Op de verschillende typen contractiele eiwit-mechanismen bij een- en meercelligen wordt door verschillende auteurs (Goldspink, White, Holberton) van het boek: Mechanics \& energetics of animal locomotion. (Eds. R.MCN. Alexander and G.Goldspink) Chapman and Hall/London, 1977.

2. Een interessante beschouwing over dit probleem geeft Dullemeijer in zijn boek: P. Dullemeijer, Concepts and approaches in animal morphology. Van Gorcum/Assen, 1983.

3. Een boeiend overzicht, en dan nog maar beperkt, van de zeer gevarieerde en tegelijkertijd zeer wezenlijke rol die deze verbindingen spelen op biomechanisch en celfysiologisch niveau biedt: Functions of the proteoglycans. (Eds.D. Evered and J. Whelan), CIBA Foundation Symposium 124, Wiley/Chichester, 1986.

Recentere informatie vindt men in Mow, V.C. et al. Biphasic and quasilinear viscoelastic theories for hydrated soft tissues. In: Biomechanics of diarthrodial joints. (Eds.V.C. Mow,A. Ratcliffe, S.L.Y. Woo), Vol. I: 215-260, Springer/New York, 1990.

4. Deze belangstelling heeft intussen zo grote dimensies gekregen, dat reeds gesproken wordt van "Een onstuimige groeimarkt (die) onvermijdelijk leidt tot wildgroei." Zie: Coen van Zwol, "Het Cultuurtje van de Fitness" NRC 3-10-1992, pagina 26. 